Please do not remove this page

RMIT

UNIVERSITY

\title{
Renovating fashion design practice: reflection and redirection
}

Splawa-Neyman, Tania

https://researchrepository.rmit.edu.au/esploro/outputs/9921859139401341/filesAndLinks?institution=61RMIT_INST\&index=null

Splawa-Neyman, T. (2013). Renovating fashion design practice: reflection and redirection. The International Journal of Design Management and Professional Practice, 6(2), 21-27.

https://researchrepository.rmit.edu.au/discovery/fulldisplay/alma9921859139401341/61RMIT_INST:Resea rchRepository

Document Version: Submitted Version

Repository homepage: https://researchrepository.rmit.edu.au

(c) Common Ground, Tania Splawa-Neyman, All Rights Reserved, Permissions:

cg-support@commongroundpublishing.com

Downloaded On 2023/04/26 20:05:42 +1000 
Thank you for downloading this document from the RMIT Research Repository.

The RMIT Research Repository is an open access database showcasing the research outputs of RMIT University researchers.

RMIT Research Repository: http://researchbank.rmit.edu.au/

\section{Citation:}

Splawa-Neyman, T 2013, 'Renovating fashion design practice: reflection and redirection', The International Journal of Design Management and Professional Practice, vol. 6, no. 2, pp. 21-27.

See this record in the RMIT Research Repository at:

https://researchbank.rmit.edu.au/view/rmit:21133

Version: Submitted Version

\section{Copyright Statement:}

(C) Common Ground, Tania Splawa-Neyman, All Rights Reserved, Permissions: cg-support@commongroundpublishing.com

Link to Published Version:

http://ijgmpp.cgpublisher.com/product/pub.239/prod.11 


\title{
Renovating fashion design practice: Reflection and Redirection
}

\begin{abstract}
How can provenance be utilised as a tool to develop a way of practicing fashion design?

The move towards sustainable and ethical modes of fashion design practice has led to a re-evaluation of the purpose of fashion design. A change in the purpose of design, demands a change in the process of design. The challenge for practitioners of fashion design is developing appropriate methodologies to achieve this goal.

Drawing on the theories and methodologies of redirective practice (Fry 2007) and reflective practice (Schön 1983), this paper suggests a template for future fashion design praxis.

Within practice-based research, seeing redirection as renovation is a helpful analogy when developing new methods of practicing design. The meaning of renovation in relation to fashion design practice may be explored through the experimental application of three possible strategies: revival, reshaping, and replacement. Embedded within these generative metaphors are fresh approaches to reconsider the utilisation, modification or relinquishment of existing designerly ways. This paper suggests a methodology whereby the use of generative metaphor illuminates the potential of provenance to facilitate a fashion design practice that is appropriate for a sustainable future.
\end{abstract}

\section{0 word summary}

This paper proposes the potential of metaphor as a tool in developing design methodology within fashion practice. Schön's (1983) reflective practice is referenced in responding to Fry's (2007) redirective theory.

\section{Profile}

Tania Splawa-Neyman is a fashion practitioner and sessional lecturer in the Fashion Program, School of Architecture and Design, RMIT University, Melbourne, Australia. She is currently undertaking post graduate study with the commencement in $\mathbf{2 0 1 0}$ of a research project titled: Remnant Gleaning: A generative metaphor for the renovation of design practice. This research aims to discover ways of practicing fashion design which are compatible with a sustainable future, through reflection on/of existing practice. Her research interests are epistemology of practice, design through make and sustainable practices. 


\section{Introduction}

"Designers make propositions about the way some thing or things could be: their propositions incorporate speculations about desired ways things will work and look; they want to know what will transform the existing into the desired; they want to find the ways and means to achieve the desired." (Downton 2003)

This paper is about proposition making. It offers propositions in response to challenges put forward by the sustainability discourse within design. It offers propositions with the view to transforming thinking through fashion design practice, within this discourse.

Concurrent with the move towards sustainable and ethical modes of fashion design practice, there has been a shift in the expectations for the role of design and therefore its objectives. These emerging roles and objectives of design are what designers are seeing as desired outcomes in their practice; the stuff that they desire to make propositions about.

Design Activism (Fuad-Luke 2009) positions the role of design as a catalyst for societal and environmental change, while Fletcher (2008) commences a discussion around the agency of fashion design within user participatory systems. These shifts in thinking around the capacity of design suggest that behaviour must evolve to support the expectations for what design should do. For design, and it's agency to change, so must its process as "the first group of people that urgently need to change their behaviour are the designers themselves" (Fuad-Luke 2009, p. 87). Fletcher (2008) poses the question, "business as usual, or more to the point, fashion as usual, is not an option. So what should we do instead?" Oftentimes for designers, a clear path or direction beyond the material driven cradle to cradle (McDonough \& Braungart 2002) approach, is difficult to see, let alone navigate. Design and sustainability theorist Tony Fry $(2007,2009)$, advocates the remaking and redirection of design, through the utilisation of past knowledge and values. This takes the conversation beyond the consideration of materials and waste to focus on the interior workings of design practice. One of the prominent facets of Fry's $(2007,2009)$ suggested framework is the importance of provenance. Provenance is implicit within design's cyclical nature, but now can it be harnessed as a tool for making change?

Redirection is a "means not an end" (Fry 2007, para. 17), it acts as a tool to guide. This is reminiscent of the reflective tools within Schön's (1983) methodology of reflective practice, which shed light on the processes of design. These insights are essential if designers are to harness their transformative powers to facilitate a fashion design practice that is appropriate for a sustainable future.

Through practice based research, connections are made between redirection, reflection, and provenance, culminating in the question: is this proposition an effective template for future fashion design praxis? 


\section{Redirective Practice}

Tony Fry's theory of redirection (Fry 2007, 2009) is a complex mesh of ideas stemming from questions thrown up by the agency of design and its outcomes. The essential drivers for redirection are the future sustainment of our world, and the sustain-ability of what we do. Sustain-ability is a process rather than an endpoint. It differs from sustainability, as it is "a means to secure and maintain a qualitative condition of being over time." (Fry 2009, p. 43) Fry argues that we now live in a world made unsustainable by design. This draws on the recognition that design designs - design has far reaching and compounding influences. The suggestion then, is that the move towards future sustainment must be by design. This forms the core of redirection and its relationship with design praxis. Furthermore, Fry (2009) puts this in a context which demands the curbing of our anthropocentric ways.

"For design, 'redirective practice' has three areas of focus: adaptation in the face of what has to change to counter the unsustainable; the elimination of what threatens sustainment by designing 'things' away; and prefiguration, which is designing in order to redirectively deal with what is coming" (Fry 2007, para. 1).

Through examination of this definition, it becomes clear that redirection has three main pathways for its dissemination - adaptation, elimination and prefiguration. Adaptation takes existing parts of practice and shapes them to become appropriate for future sustainment. Elimination suggests that some parts of practice and its outcomes are simply not redeemable in terms of sustain-ability. Prefiguration perceives the outreaching impacts of emerging design ideas, in terms of sustainable goals. These considerations must remain at the forefront of any strategy for redirection.

Redirection forces designers to rethink design, but beyond this, to remake their thinking (Fry 2009, p. 206). To achieve this, the suggestion is to get inside the practice, and examine its workings to see what there is to work with and what can be done. The challenge for any fashion design practice, is how to approach this, where do you start? What is there in the designer's tool box that could assist this redirective aim?

\section{The potential of provenance}

It is true that design is referential and cyclical by nature. Michl (2002), through seeing design as redesign, posits that existing knowledge is the stuff that design is made of. Furthermore, Downton finds that each practitioner's individual designerly ways and skills contributes to their unique design outcomes as "the interactive, iterative loop continues to evolve" (Downton 2004, p. 16).

This reiterative quality within design process is where provenance comes into play. Provenance is defined as the place of origin or the record of ownership of a work of art (Macquarie dictionary 2009). I see provenance having both of these senses as it relates to design practice. Pertaining to the individual, provenance is a descriptor of the knowledge that is bound to and originates with the practitioner themselves, as well as a record of the evolution of this knowledge over the course of the 
designers practice. This perspective also relates to provenance in the greater design sphere where the originators of ideas, skills and ways of thinking are recognised, while subsequent designers become custodians of this knowledge as they develop further iterations. This existing influence of provenance is utilised within design development, either unknowingly by the designer or through intentional research. Downton $(2003,2010)$ identifies three types of design research; research about design, research for design, and research through designing (ibid.). Research about design encompasses the seeking of the what and why of design, alongside the "history of objects and how they came about" (Downton 2003, p.37). Research for design seeks sources and ideas and gathers tools, data and skills which will enable designing. Research through design is where the ideas and inspiration come from the activity of designing itself, and is particularly entrenched within the practice of the designer themselves. These accounts of design research show where provenance originates, and hint at how it will manifest within design process. Provenance is particularly observable within the field of fashion design. The fashion system is cyclical, within which "certain styles come around again and again" (Craik 2009, p. 106).

Given this established place within design process and the fashion system, provenance is poised to act as a transformative influence in developing redirective practice. Fry (2009) does suggest that there is potential in what has come before, as "the rematerialization of the culture by making new forms, knowledge and values from the old." (Fry 2009, p. 102) will "recreate a sustaining social ecology as a foundation of change" (ibid.). There is an opportunity for the designerly trait of provenance to be utilised when challenging the foundations of fashion design practice. However, what isn't clear is how practitioners, in meeting the demands of redirective practice, can facilitate this endeavour.

\section{Reflective tools}

Schön's seminal work, The Reflective Practitioner: How Professionals Think in Action (Schön 1983), explores how professionals, including those from design fields, go about solving problems within their practice. Schön describes design as a "reflective conversation with the situation" (Schön 1983, chapter 3 heading). The designer shapes this situation through a conversation that occurs within. This conversation is reflective, and as "the situation talks back" (Schön 1983, p. 79) the designer "responds to the situation's back talk" (ibid.). By knowingly engaging in reflective practice, design practitioners gain insights into the nature of their own propositioning. Reflection within the situation, or "reflection-in-action" (Schön 1983, p. 49) not only recognises the moves made within design process, but also perceives the implications of those moves. This elevated awareness, through the designer's appreciation of a move's consequences, affects a "changing stance toward the situation with which he converses" (Schön 1983, p. 95). In response, the designer's changing stance yields an additional set of moves, which when evaluated, ascertain the effectiveness of the proposition. The richness of reiteration within the design process is intensified, as the designer, in responding to the situation's back talk, receives further talk back. 
This parable of the reflective conversation illuminates the reiterative nature that lies within design's process. Thus, reflective practice appears to be an appropriate methodology for the exposure and utilisation of provenance within design practice. Furthermore, "reflection-in-action" (Schön 1983, p. 49 ) is a constructive way of discovering design's repercussions, and therefore has the potential to facilitate redirection.

The self awareness imparted to the designer through reflective practice, provides opportunities to punctuate or interrupt the conversation within the design situation with redirective aims. The reflective tool of "seeing-as" (Schön 1983, p. 139) provides a way of instigating this break in the design conversation. When "seeing this situation as that one, one may also do in this situation as in that one" (ibid.) "Seeing-as" (ibid.) allows a practitioner to utilise prior knowledge from a familiar design situation, as a precedent for solving problems in the current one. This is providing that the current problem is analogous to one already solved. When the prior knowledge, or exemplar, is outside the practitioner's usual realm of experience, and "when the two things seen as similar are initially very different from one another" (Schön 1983, p. 183), this transforms the analogy to a generative metaphor. For a metaphor to be generative, it must generate "new perceptions, explanations, and inventions" (Schön 1983, p. 185). Generative metaphors are particularly useful for prompting the punctuation or interruption of the conversation within the design situation, which redirection demands. This is through the very nature of the generative metaphor - it is outside of the usual mode of thinking for the practitioner, and it is fruitful in making new connections and insights. The outcomes from thinking through generative metaphors oscillate between the renewed appreciations of existing provenance, and entirely new ways of approaching design problems.

\section{Renovation: a generative metaphor}

As discussed, the successful conception of a suitable generative metaphor will illuminate the potential of provenance within the design situation and initiate steps on the redirective pathway. Through my own practice based research, in response to the nexus I have forged between redirective and reflective practice, I have conceived the generative metaphor of renovation. Within my research I see redirection as renovation. It acts as a metaphor for the redirection that I am attempting to instil in my own practice, and is proving to be generative through the insights that are being revealed.

Furthermore, I see renovation as a generative metaphor for the redirective approach of prefiguration, as any act of renovation must be preceded by the prediction of its suitability in light of a desired future outcome.

My understanding of renovation is based on my own ongoing experience of renovating the late 1930's house in which I dwell. As I see myself as its custodian, where possible I have been respectful to the provenance of the building and retained the existing features of the house. This is where I have seen value in that which is rare, irreplaceable or difficult to replicate. At other junctures I have adapted parts of the structure and its fixtures, while sometimes it has been appropriate to make complete 
changes and remove some original elements. The empathy of this attitude towards renovation reinforces the connection I make between redirection and renovation.

The other fundamental approaches to redirection: adaptation and elimination, share a commonality with the guidelines I work within when renovating. Respect for what came before is a major factor in my decision making, which draws an obvious correlation with provenance, but also casts a new light on these redirective approaches. When renovating, any decision is preceded by the consideration of three prospective modes of action: revival, reshaping and replacement. These prospects are generative metaphors in themselves, and serve to clarify the unfamiliar or puzzling aspects of adaptation and elimination when attempting redirection.

\section{Revival}

Revival nurtures that which is worthy of reuse in its current form. This first step in renovation considers original, existing features, revealing renewed appreciations of elements that are aged, unique, hidden and perhaps fallen into disrepair. There may be dust to blow away, paint to strip off, or rust to remove, actions which are worthwhile in order to preserve that which is appropriate and fitting in its current place and context.

As a generative metaphor, revival offers further insight into the nature of provenance. A process analogous to the removal of dust, rust or paint is required to uncover the potential of skills, approaches and materials embedded in the existing practice. These might be activities which the practitioner has forgotten, is out of practice with, or at the time sees as irrelevant. Revival gives a criterion for considering the worth of such things; that they must be appropriate and fitting, in this case within the context of redirection.

\section{Reshaping}

Reshaping renders the useless as useful again through conversion and adaptation of what exists. The elements in question have some positive attributes in relation to the overall goals for the renovation, however, they don't work in their current setting either due to their placement, or their form. Manipulation is required, through a change in context, structure or both.

This phase gives the practitioner a first line strategy to try when certain approaches or actions within their design situation seem slightly out of line with redirective aims. The generative metaphor of reshaping proposes that the modification of the practitioner's ways may be a solution. Alterations of approaches or actions may shape them for a better fit, or a context shift may put what the designer knows to better use in another part of the design conversation.

\section{Replacement}

Replacement guts out the non-redeemable to solve the problem, or performs a complete shift to ask what the problem in fact is. Sometimes parts that are outdated or beyond repair just have to go. Modernisations that make improvements in efficiency, space utilisation or even aesthetics warrant the removal of the original. At times the substitute is more sympathetic to maintaining the provenance within the renovation than what was replaced, or may affect a whole new function or appreciation of 
the space. Some problems may have unseen causes, such as cracks caused by weak foundations. Awareness of the interconnectedness of such elements is heightened, and replacement is compelled to go beyond surface appearances.

Existing approaches, actions and outcomes that are completely incongruous with redirective practice must be relinquished. This generative metaphor expands the awareness of the reasons for replacement, beyond the acquisition of shiny new things. Alternative approaches and actions in the design situation must be compatible with redirective aims, and have the potential to become transformative within the situation. New appreciations of connections and influences are prompted, which have the potential to uncover deeply rooted and previously masked problems within design practice.

\section{A Template for Future Praxis?}

The amalgamation of fundamental ideas from both redirective and reflective practice has proven to be fruitful in generating the thinking required for developing a possible methodology for redirection. Rethinking has evolved into the remaking of how I think, influencing the formulation of a proposition which will potentially form the basis of a template for future fashion design praxis. This proposition is summarised thus:

Reflective Practice, through the utilisation of "seeing-as" and generative metaphors, originates moves to actualise the Redirective aims of adaptation and elimination. The Reflective conversation with the situation is driven by the criterion imparted by Provenance, and Redirection's other aim, prefiguration. The overarching generative metaphor sees Redirection as Renovation.

A network is formed between Redirection, Reflection, Provenance and Renovation, which through various interactions stimulates new insights within practice. The interplay of the generative metaphors embedded in the proposition give direction as to where the punctuation or interruption points could or should occur within the reflective conversation.

This network clarifies some aspects of the reflective conversation, but in other ways it muddies the situation further. This increasing complexity can risk making this proposition unworkable in practice. For practitioners it is a balancing act between over simplicity and lack of truth in their approach, and a level of unnecessary complexity. As noted earlier, redirective practice itself is incredibly complex, so perhaps any methodology that works towards its undertaking can only be complex itself.

Further testing of this proposition is required to observe its effectiveness and to troubleshoot these identified problems with complexity. More specific examples of the implications and effects that are provoked through the application of the generative metaphors are required. As my practice based research is in its formative stages, the required level of rigour to fully test my proposition is outside where my research currently stands, and also outside the scope of this paper. Further work in the future will ask: is this proposition an effective template for future fashion design praxis? 


\section{Concluding Remarks}

My proposition effectively connects the ideas and thinking around Redirection, Reflection, Provenance and Renovation, where generative metaphor is the catalyst for actuating fashion design's reflective conversation. Weighing the discussed limitations against the perceived benefits of this proposition leaves scope for further iterations and refinement, while there is potential for immediate application within design situations when addressing sustain-ability.

Fundamentally, my proposition provides a way of thinking about fashion design practice, as well as tools for thinking through fashion design practice. These activities stimulate progress towards the establishment of a robust template for fashion design practice that is appropriate for a sustainable future.

\section{References}

Craik, J 2009, Fashion : the key concepts, English ed. edn, Berg, Oxford ; New York.

Downton, P 2003, Design research, RMIT Publishing, Melbourne.

---- 2004, Studies in design research : ten epistemological pavilions, RMIT University Press, Melbourne.

---- 2010, Three ways of knowing, Research Strategies lecture series, RMIT University, March 10.

Fletcher, K 2008, Sustainable fashion and textiles : design journeys, Earthscan, London ; Sterling, VA.

Fry, T 2007, 'Redirective practice: an elaboration', Design philosophy papers, no. 1, 2007.

---- 2009, Design futuring : sustainability, ethics, and new practice, English ed. edn, Berg, Oxford, UK ; New York, NY.

Fuad-Luke, A 2009, Design activism : beautiful strangeness for a sustainable world, Earthscan, London ; Sterling, VA.

Macquarie dictionary, 2009, 5th ed. edn, Macquarie Dictionary Publishers, [Sydney].

McDonough, W \& Braungart, M 2002, Cradle to cradle : remaking the way we make things, North Point Press, New York.

Michl, J 2002, 'On seeing design as redesign : an exploration of a neglected problem in design education', Scandinavian journal of design history, vol. 12, pp. 7-23. 
Schön, DA 1983, The reflective practitioner : how professionals think in action, Basic Books, New York. 